\title{
Market values
}

John L. Casti

Economics: Mathematical Politics or Science of Diminishing Returns? By Alexander Rosenberg. University of Chicago Press: 1992. Pp. 266. \$37.50, $£ 25.95$.

IT has often been said that economics is either the hardest of the soft sciences or the softest of the hard sciences. In this provocative and important work, Alexander Rosenberg, professor of philosophy at the University of California, Riverside, claims that it is neither, for the simple reason that by whatever criteria you use to label an area 'scientific', economics fails to measure up.

How is one to judge whether economics, or any other field of study for that matter, is in any way scientific in its goals and methods? According to Rosenberg, one litmus test for the scientific is that a genuine science improves the predictive powers of its theories over time. Economics has failed dramatically by this standard, being limited to generic predictions of the sort exemplified by the statement made in 1989 by the investment house Drexel, Burnham, Lambert: "There are several alternative outcomes which are possible for the US economy in 1990". Rosenberg attributes a large part of the failure of economics to improve its predictive powers to the fact that the explanatory variables of folk psychology - beliefs, desires and preferences - that economists build their theories on "cannot be linked up with the rest of science. They cannot even be realized, exemplified, or instantiated by the brain in theoretically tractable ways." So if economics is not a natural science, what is it?

Perhaps it is a biological science. Pursuing this possibility, Rosenberg examines the biologically motivated theory of consumer behaviour advocated by Gary Becker, a theory that contributed greatly to Becker's winning this year's Nobel prize in economics. This theory draws parallels between an individual's economic needs and evolutionary biology, arguing that by focusing on populations rather than individuals, it is indeed possible to make meaningful predictions about aggregates such as market demand and supply. Sad to say, Rosenberg concludes that treating the theory of rational choice as a theory about biological systems holds out little hope of providing a useful line of development for economic theory.

As a final possibility, Rosenberg asks if economics is not an empirical science, then perhaps we should regard it as a branch of applied mathematics. Indeed, both the defenders and detractors of economic theory have found its intellectual core in its mathematical expression. The central aspect of the 'mathematization' of economics is, Rosenberg claims, the identification of the intentionality of economic agents with the equilibria of, for example, a utility function.

Euclidean geometry was once styled the 'science of space', but calling it a science did not make it one. Drawing parallels between the development of economics as a mathematical activity and the development of geometry, the author notes that while we can certainly call economics the science of the distribution of scarce resources, this appelation again does not make it a science. Economists, like geometers, have blithely carried on their business of proving theorems without giving much thought to the issue of the cognitive status of economic theory. And the assumptions underlying the theorems of both euclidean geometry and neoclassical mathematical economics seem to rest on the same shaky ground. In this sense, the parallel postulate of Euclid and the assumption of economic rationality are of a kind. Rosenberg finally concludes that thinking of economics as mathematics enables us to explain a wide variety of the failings of economic theory to match up to economic facts.

The bottom line of Rosenberg's thesis is that the best way to think of economics is not as a science, but rather as a combination of political philosophy and applied mathematics (with emphasis on the mathematics). Given the central role that economics seems to play in arriving at public policy decisions, this should be a sobering conclusion for all of us. This well argued and researched book should therefore be read by politicians, government mandarins and, more generally, the concerned lay public. But unfortunately its resolutely academic tone and rather dry literary style are unlikely to attract the attention of those for whom its message would do the most good. Perhaps some day someone somewhere will translate Rosenberg's arguments into plain everyday English and publish them in a form accessible to everyone. In the meantime, we can hope that intellectual osmosis will work its magic and Rosenberg's important message that economics is not and never can be a science will make its way from the rarefied halls of academia to the smokefilled backrooms of Washington, Wall Street and Whitehall.

John L. Casti is at the Institute for Econometrics, Operations Research and System Theory, Technical University of Vienna, Vienna, Austria, and the Santa Fe Institute, Santa Fe, New Mexico 87501, USA.

\section{The sound of music}

Michael Neve

The Volcano Lover: A Romance. By Susan Sontag. Farrar, Straus and Giroux/Jonathan Cape: Pp.419. \$22, £14.99.

THIS story centres on a famous ménage à trois of the late Enlightenment, the relationship between the British ambassador to Naples, Sir William Hamilton, a Fellow of the Royal Society, admirer of volcanoes and a dealer in paintings and Greek vases; Emma Lyon, the one time prostitute who became his mistress and his second wife; and Horatio Nelson, the naval hero and victim of Trafalgar. A great deal of Sontag's interest centres on the varieties of ways in which this trio and other characters observe the world and are observed in their turn. They observe Vesuvius, which constantly threatens eruptions that can both terrify and fascinate. Hamilton, more than 30 years older than Emma, and a man who had started collecting art objects in early life through an unhappy first marriage and an incapacity to get involved, is seen as a connoisseur of ruins. He is not looking, but looking away. This also allows him to look at Vesuvius, but from a distance. When he meets his future wife Emma, he is physically excited by her but also has to add her to his art collection, putting her in different classical postures, such as that of Dido or Ariadne. Into the emptiness that sustains Hamilton's need to make living bodies into statues arrives the figure of Nelson. As a result, seven years after marrying Hamilton in 1791, Emma turns the connoisseur and diplomat into a kindly-regarded cuckold. The relationship between Emma and Nelson in its turn migrates into a form of gothic romance before Nelson assists in the destruction of Neapolitan republicanism and eventually dies heroically at Trafalgar. A portrait of modern Europe has been painted by looking at the lives of this trio.

Sontag's excursion into the world of the historical novel has aroused considerable interest, since she tells a story ostensibly set in Naples in the eighteenth century while managing to introduce comments on the modern world that are clearly her own. Part of the interest, therefore, lies in trying to work out what she is up to. What is the status of the 